\title{
EDITORIAL
}

Este número da Revista Interfaces Científicas Educação conta com uma variedade de estudos que tratam de elearning, políticas de formação continuada, novas tecnologias da informação e comunicação, educação superior, História das instituições escolares no século XIX, a qualidade da educação na contemporaneidade, bem como a articulação entre ensino, pesquisa e extensão.

Uma pesquisa bibliográfica foi realizada por Ana Isabel Mateus da Silva a fim de discutir e esclarecer termos como elearning e blearnig, no sentido de identificar a melhor terminologia a ser utilizada, especialmento no que diz respeito a educação a distância e ao processo de aprendizagem colaborativa. A autora defende que o termo elearning, menos centrado nos aspetos tecnológicos e mais próximo do potencial pedagógico decorrente do uso das tecnologias de redes no planejamento de situações de formação a distância, sendo baseado na interação e na colaboração, construa aprendizagens significativas, utilizando a aprendizagem colaborativa.

A partir de documentos institucionais e depoimentos, Tereza Cristina Cerqueira da Graça desvela o percurso histórico do Programa Hora de Estudo, instituído nos anos noventa do século XX pela Secretaria da Educação. Essa ação se constituiu em uma parte da política de formação continuada instituída para os professores da rede municipal de ensino de Aracaju. A autora afirma que, apesar de ter sido criado em atendimento às reivindicações do magistério, as alternâncias quanto ao foco de formação contínua das gestões que se sucederam na Secretaria, bem como as instabilidades da relação poder público-sindicato contribuem para a ausência da maioria dos professores, já que o PHE não vem sendo mantido com a regularidade e a intensidade necessárias. Além disso, esse fato é reforçado pela falta de disposição dos professores em investir na sua própria formação por esta via.
Andréa Karla Ferreira Nunes e Kalyne Andrade Ribeiro fazem uma discussão sobre a importância da formação continuada docente através do uso das novas tecnologias da informação e comunicação, enfatizando a importância dos programas de políticas públicas e analisando as contribuições do Programa Salto para o Futuro no Estado de Sergipe. Sendo uma pesquisa ainda em andamento, os resultados parciais demonstram que o Programa Salto para o Futuro tem contribuido significativamente no processo de construção da conscientização da relevância da formação continuada dos docentes, bem como da utilização das novas tecnologias. Os conhecimentos adquiridos pelos professores possibilitam qualificação, criam uma ambiente reflexão e de aprendizagem, contribuindo para a transformação da escola através da criação de situações de reflexão e aprendizagem, trazendo uma mudança na postura do professor e consequentemente, melhorando a qualidade da educação.

As diferentes trajetórias de inserção de professoras licenciadas que protagonizaram os primórdios da implantação do ensino superior estadual em Feira de Santana, Bahia é o tema de estudo de Ana Maria Fontes dos Santos. A Faculdade Estadual de Educação (FEEFS) foi criada em 1968, sendo a primeira no interior do Estado que tinha como objetivo a formação de professores. A criação dessa instituição durante a ditadura militar, sobretudo a partir de 1968, com a edição do Ato Institucional $n^{\circ} 5$, colocou a Faculdade em um cenário que reforça esse local como instância formal de poder. É nesse contexto que as trajetórias de três professoras que adentraram ao campo universitário interiorano a partir de diferentes lugares no campo científico e político, situavam-se, ou eram postas, às sombras das principais lideranças, no âmbito das lutas de instituição do referido campo.

Cristiano Ferronato, Simone Amorim, Leyla Santana, Joseane da Silva e Joelson dos Santos apresen- 
tam questões iniciais sobre o processo de organização da instrução secundária na província da Parahyba do Norte, entre os anos de 1836 e 1846, tendo como fonte os Estatutos do Lyceu Provincial da Parahyba do Norte publicados em 1846. Assim, foi possível compreender como a cultura escolar foi organizada e consolidada a partir dessa normatização realizada pelo poder público. Nesse sentido, os autores afirmam que o Lyceu Provincial da Parahyba do Norte é um marco importante na instrução secundária brasileira e paraibana, pois foi a partir da sua criação que foram lançadas as bases da organização do ensino público secundário na Província. Portanto, a reconstituição da história dessa instituição traz alguma contribuição para o entendimento não somente da História da Educação local, mas também nacional.

O debate educacional sobre a qualidade constitui-se em um dos principais desafios da educação na contemporaneidade e esse é o tema do texto de Betisabel Vilar de Jesus Santos. Para tal, a autora tomou como referência os dados da Associação Nacional de Pós-Graduação e Pesquisa em Educação (ANPED), de 2009 a 2011 e o banco de teses da Coordenação de Aperfeiçoamento de Pessoal de Nível Superior (CAPES), de 2007 a 2011, dentre outras fontes bibliográficas. Assim, ainda que seja um tema conflituoso, conclui-se que o discurso oficial está mais próximo daquele preconizado pelas entidades científicas, pelas instituições que congregam segmentos organizados da educação e da sociedade civil, que houve uma valorização da questão da qualidade da educação com a promulgação da Constituição de 1988, mas que é necessário haver uma descentralização desses sistemas a fim de que haja uma melhor distribuição de recursos financeiros e pedagógicos entre as escolas.

A relação ensino-pesquisa-extensão foi discutido por Antonio Roberto Seixas da Cruz e Murilo Oliveira Almeida, sendo o tema visto por meio da ótica de cinco docentes de mestrados da Universidade Estadual de Feira de Santana. A problemática do texto reside no fato de que as discussões sobre a formação de pro- fessores têm enfatizado os aspectos das políticas públicas e das bases legais sobre a profissão docente, mas esquecendo aspectos que também são importantes para o âmbito universitário. 0 estudo, que se baseia na Teoria das Representações Sociais, identificou um elemento comum às falas dos docentes: o ensino, a pesquisa e a extensão são elementos inerentes à prática docente universitária, integrando o processo pedagógico, mas por vezes não é possível identificar esses elementos em conexão com as práticas docentes de sala de aula.

Após essas considerações sobre os textos aqui publicados é possível inferir que eles possuem, além de outras, a qualidade de instigar os leitores a partir dos títulos. Poder ler e conhecer pesquisas distintas ou até mesmo aproximadas a partir de diferentes referenciais teóricos nos permite alcançar o grau de erudição necessário à vida acadêmica, pois o conhecimento pode nos levar além do que se possa imaginar.

\section{Boa leitura!}

Simone Amorim

Doutora em Educação Programa de Pós-Graduação em Educação - UNIT 